\title{
Chapter 5 \\ Disruptions and Diversions: \\ The Demographic Consequences \\ of Natural Disasters in Sparsely \\ Populated Areas
}

\section{Dean B. Carson, Doris A. Carson, Per Axelsson, Peter Sköld, and Gabriella Sköld}

\begin{abstract}
The Eight Ds model (Carson and Carson 2014) explains the unique characteristics of human and economic geography for sparsely populated areas (SPAs) as disconnected, discontinuous, diverse, detailed, dynamic, distant, dependent and delicate. According to the model, SPAs are subject to dramatic changes in demographic characteristics that result from both identifiable black swan events and less apparent tipping points in longer-term processes of demographic change (Carson et al. 2011). The conceptual foundations for this assertion are clear. Populations in SPAs can experience large and long-term impacts on the overall demographic structure as a result of decisions by a relatively small number of people. High levels of migration and mobility cause constant shifts in the demographic profile and prime SPAs to adapt to many different demographic states (Carson and Carson 2014). The Northern Territory of Australia, for example, experienced previously unseen waves of pre-retirement aged migrants in the past decade or so (Martel et al. 2013) as evidence of detailed but important changes to past trends. However, while dramatic demographic changes are conceptually possible and occasionally observable, there have been few attempts to examine the conditions under which such changes are likely to occur or not to occur. This is an important question particularly in relation to black swan events such as natural disasters because effective disaster management policy and planning is at least partially dependent on understanding who is affected and in what ways (Bird et al. 2013).
\end{abstract}

\author{
D. B. Carson ( $ه)$ \\ CQUniversity Australia, Rockhampton, Australia \\ e-mail: d.carson@cqu.edu.au \\ D. A. Carson · P. Axelsson · P. Sköld · G. Sköld \\ Umeå University, Umeå, Sweden \\ e-mail: doris.carson@umu.se \\ P. Axelsson \\ e-mail: per.axelsson@umu.se \\ P. Sköld \\ e-mail: peter.skold@umu.se
}


Keywords Flood $\cdot$ Cyclone $\cdot$ Famine $\cdot$ Sparsely populated $\cdot$ Eight Ds

\subsection{Introduction}

The Eight Ds model (Carson and Carson 2014) explains the unique characteristics of human and economic geography for sparsely populated areas (SPAs) as disconnected, discontinuous, diverse, detailed, dynamic, distant, dependent and delicate. According to the model, SPAs are subject to dramatic changes in demographic characteristics that result from both identifiable black swan events and less apparent tipping points in longer-term processes of demographic change (Carson et al. 2011). The conceptual foundations for this assertion are clear. Populations in SPAs can experience large and long-term impacts on the overall demographic structure as a result of decisions by a relatively small number of people. High levels of migration and mobility cause constant shifts in the demographic profile and prime SPAs to adapt to many different demographic states (Carson and Carson 2014). The Northern Territory of Australia, for example, experienced previously unseen waves of pre-retirement aged migrants in the past decade or so (Martel et al. 2013) as evidence of detailed but important changes to past trends. However, while dramatic demographic changes are conceptually possible and occasionally observable, there have been few attempts to examine the conditions under which such changes are likely to occur or not to occur (see also Chap. 6). This is an important question particularly in relation to black swan events such as natural disasters because effective disaster management policy and planning is at least partially dependent on understanding who is affected and in what ways (Bird et al. 2013).

The purpose of this chapter, therefore, is to begin the process of identifying the conditions under which dramatic demographic responses to natural disasters in SPAs might occur. In the process, we introduce two new 'Ds' with which to describe the nature of demographic change. We propose that natural disasters such as cyclones, floods, earthquakes, bushfires, landslides, avalanches and crop failures present the

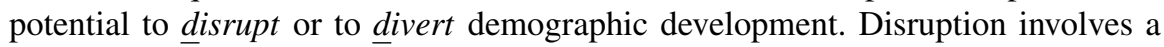
temporary break in demographic development after which the pattern apparent before the disaster resumes. Diversion involves the transition to a new pattern clearly and substantially distinct from the pre-event state. Disruption and diversion can be considered as end points on a scale with attributes such as the length of time taken to revert to pre-event development patterns and the number and type of demographic characteristics that change post-event along with the severity of the change determining where an event might be positioned on that scale.

The chapter focuses on two apparently dissimilar natural disasters which are the Great Deprivation crop failure(s) in northern Sweden in 1867-8 and the flooding of the Katherine-Daly river basins in the Northern Territory of Australia in 1998 caused by Cyclone Les. While the Great Deprivation affected large areas of Norway, Sweden and Finland, this chapter will focus on the parish of Gällivare in Sweden's 
Norrbotten County due to the region's prominent role in the economic and demographic development of the north at the time through forestry and mining. Figures 5.1 and 5.2 shows the locations of Gällivare parish and the Katherine-Daly river basins.

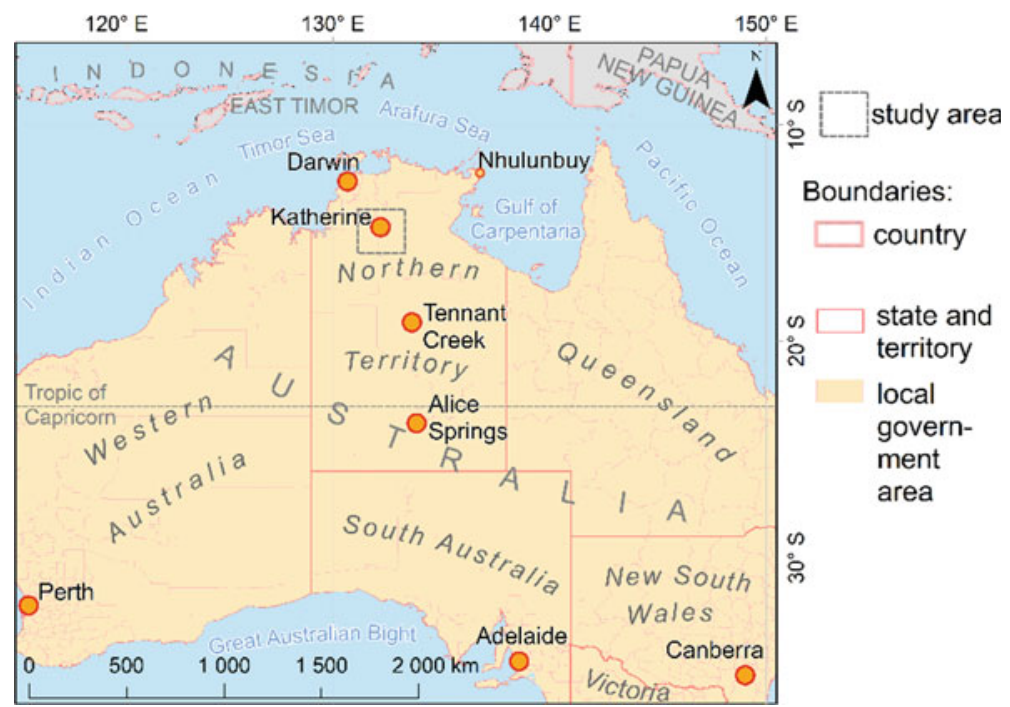

Fig. 5.1 Location of case site Katherine-Daly region, Australia (Cartography by Karácsonyi)

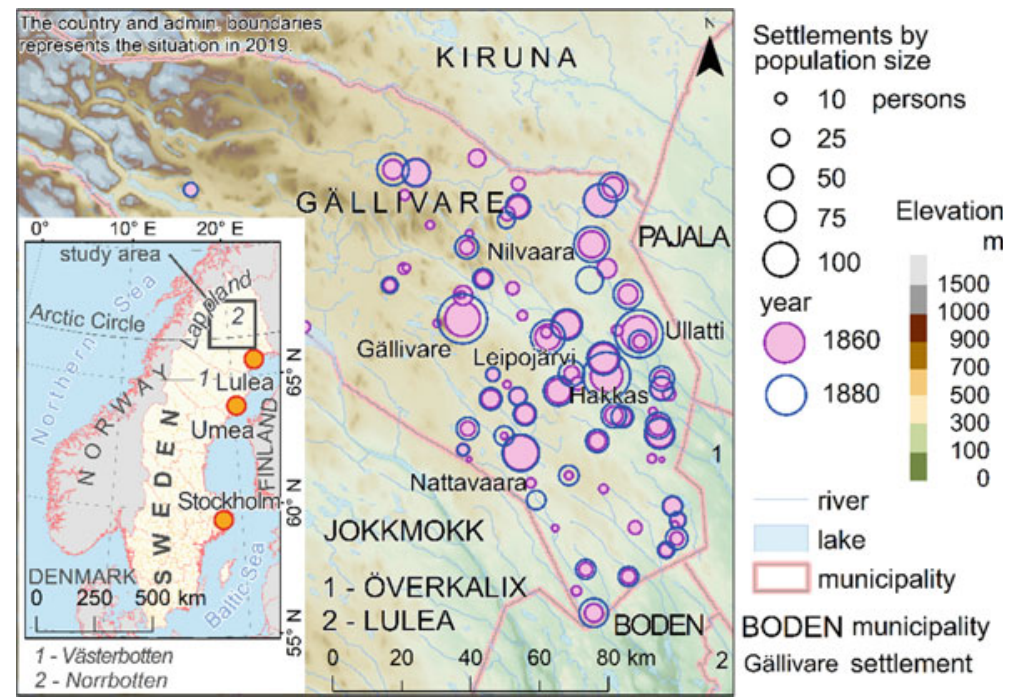

Fig. 5.2 Settlements in Gällivare, 1860 and 1880 (Authors: B. Carson, A. Carson, Axelsson, P. Sköld, G. Sköld, cartography by Karácsonyi) 
Research has not been published about the impacts of the Great Deprivation on Gällivare, but Nordin's (2009) analysis of long-term demographic change in this and other northern parishes shows a brief (two or three years) slowing of population growth around the time of the crop failures amid an extended period of population growth before and after the event. This is primae facie evidence (at least at the gross population level) of a demographic disruption. In contrast, grey and academic literature relating to the Katherine-Daly region reveals a dramatic change in gross population trends (from substantial increase in the 1980s and early 1990s to a long period of stagnation persisting to the present time), along with substantial (and persistent) changes in the proportion of Indigenous people and women in the population (Harwood et al. 2011). This is primae facie evidence of a demographic diversion.

\subsection{The Challenges of Identifying Demographic 'Impacts'}

Attributing demographic changes in SPAs to black swan events is difficult precisely because of the dynamic nature of populations in those areas. Their susceptibility to dramatic change exists, even in the absence of such events. In the case of migration impacts, for example, high levels of migration already occurring in SPAs might be difficult to separate from migration specifically related to a natural disaster (Adamo and Sherbinin 2011). Likewise, demographic transitions in fertility and mortality can occur relatively quickly but sporadically in SPAs (Taylor 2011), such that bubbles and craters (Martel et al. 2011) are expected characteristics of distributions of demographic characteristics of SPAs in most circumstances.

Analyses of demographic change are also impacted by the modifiable areal, modifiable temporal and modifiable social unit problems (MAUP, MTUP, MSUP) (Koch and Carson 2012). The MAUP is concerned with the problem of spatial scale when analysing statistical (e.g. population) data, as results can change according to the levels of scale applied to the analysis. It is difficult to ascertain at what spatial scale the demographic impacts of natural disasters can be best understood. On the one hand, natural disasters may have physical impacts that are highly localised as is the case with landslides and avalanches, and sometimes bushfires and flooding and even violent storm events. On the other hand, public perceptions often attach these events to broad geographical ideas such as the north, the Arctic or the tropics. While researchers must be careful in recognising the physical boundaries of event impacts, they should also not underestimate the power of perceived risk boundaries in influencing demographic behaviour (Ford et al. 2006). In this chapter, we are interested in somewhat local impacts, which bring the additional challenge of deciding what demographic characteristics to observe, and how to represent them. Most demographic rates are designed for application to relatively large populations of 100,000 persons or more while here, we are working with populations much smaller. In the absence of well-established demographic analysis techniques for small populations (Taylor 2014), we have restricted our analysis to broad indicators that include gross populations and percentage of persons with particular characteristics. 
Similar to the MAUP, the MTUP refers to the impact that different temporal dimensions can have on the outcomes of data analysis. This is important in the context of demographic change following natural disasters, whereby Ford et al. (2006) noted that demographic change may be a long-term consequence of exposure to the risk of natural disasters as much as a short-term response to a single event. In fact, the expectation of experiencing natural disasters in SPAs may make demographic structures quite resilient to a single major event, and changes in demographic behaviour may be a cumulative effect of relatively minor events.

This last statement also reveals the challenges of the MSUP, which refers to the problem that the outcomes of data analysis may differ according to the social units selected for analysis. McLeman's (2010) research in Canada showed that specific individuals may migrate out of northern communities as a result of extreme weather events, but migration flows may persist with out-migrants being replaced by inmigrants with similar characteristics. In this way, the demographic behaviours of individuals might be impacted by the event, but the demographic behaviours of the population as a whole remain relatively stable. Bailey (2011) noted, for example, that communities with high pre-existing demographic volatility are likely to experience high demographic volatility as a result of a natural disaster. This is not the only problematic dimension of the MSUP, with several researchers identifying that the differential impacts of events on various social groups (defined by ethnicity, social status, gender and even religion) can be hidden in higher level analyses (Ellis 2009).

These unit problems are apparent in trying to summarise the impacts of the Great Deprivation as reported in the academic literature. That literature is replete with apparent contradictions and counter-intuitive observations. The Great Deprivation was a severe shortage of food resulting from consecutive crop failures in the Nordic countries in 1867 and 1868 . The 1867 crop failures were caused by a long, cold and wet winter, while the 1868 failures were caused by drought. The crop failures affected at least Finland, Norway and Sweden (Nelson 1988). Finland, during the Great Deprivation, has been the focus of much attention regarding demographic impacts. This is because of estimates that state nearly $10 \%$ of the population there died as a direct result of the food shortage (Jantunen and Ruosteenoja 2000). Debate continues as to the impacts of the Great Deprivation across the entire region, but it is apparent that impacts differed both between and within countries. It has been common, for example, to attribute the substantial increase in Swedish (and Norwegian) emigration to North America at the end of the nineteenth century to the Great Deprivation (Akenson 2011), although emigration from Finland to North America was comparatively rare. More recent research, however, suggests that either the Great Deprivation did not have such an immediate impact on Swedish emigration (with the substantial increase coming at least a decade after the event), or emigration was largely from southern parts of Sweden (Alestalo and Kuhnle 1987). Likewise, while direct Finland-America migration was limited, it has been estimated that up to $20 \%$ of Finns who migrated to other parts of Scandinavia (mostly northern Sweden) at the time of the Great Deprivation ultimately on-migrated to America (Newby 2014). This simple example reveals aspects of the MAUP (different migration patterns observable at different spatial scales), MTUP (different patterns observable depending on 
the 'lag' times allowed between the Great Deprivation and emigration) and MSUP (the behaviours of people in northern Sweden have been hidden within the analyses of the total Swedish experience (Doblhammer et al. 2013), just as the behaviour of Finnish on-migrants may have been hidden by both time and the relatively small size of the population within northern Sweden).

Migration responses to the Great Deprivation are not the only subject of contention in the literature. While there appears to be consensus that fertility rates decreased during the immediate Great Deprivation period (typically considered to be 186770 allowing for recovery time) but recovered shortly thereafter, the impacts on life expectancy and mortality continue to be debated. Hayward et al. (2013) claim lower life expectancies for people born around the time of the Great Deprivation, while Saxton et al. (2013) claim that life expectancy impacts were very small. The MSUP might be important here, with specific population groups such as landless labourers, Sami (Nordin and Sköld 2012), rural dwellers, and Finnish migrants believed to have been more dramatically affected than others.

Overall, the published evidence from the Great Deprivation suggests a demographic disruption lasting between three and five years and affecting fertility, mortality and migration. These conclusions are tempered by observations of substantial spatial and social variation, particularly for mortality, migration and possibly also life expectancy. These presumed impacts of the Great Deprivation are generally consistent with the observations made about other 'famine' events in western and northern Europe (O Grada 2007). In general, local impacts were less where there were higher industrialisation and urbanisation. Industrialisation and urbanisation generally reduce reliance on local food sources, increase access to public and private sources of famine relief, and provide the resources for individuals and families to use adaptation strategies such as long-term and short-term migration and changes of occupation (Isacson et al. 2013).

The Great Deprivation is seen as the last of the European famines to result from natural events (although food scarcity has since occurred as a result of war and economic depression). The nineteenth century saw other years of crop failure (notably 1809, 1832-33 and 1857-58 (Bengsston and Dribe 2002)), with industrialisation and urbanisation changing food supply chains and reducing the reliance of communities on local food production. Nevertheless, crop (and stock) failures as a result of droughts, floods and other natural events continue in many SPAs in industrialised (and post-industrial) nations, and their demographic impacts continue to be debated. While the risk of food scarcity is low, there are still likely to be substantial demographic impacts linked to economic and social consequences of bad seasons. Drought, cyclone, flood and fire events have been linked to out-migration (particularly youth out-migration), increased suicide rates, and urbanisation in SPAs in Australia, Canada and the USA (Hogan et al. 2014; McLeman and Smit 2006).

The specific literature on the Katherine-Daly cyclone-induced flood event of 1998 will be reviewed later in this chapter, but similar events have been researched from a demographic perspective. Cyclones and floods have the potential to physically destroy towns and settlements, although the typical response (in the past century at least) has been to rebuild those towns and settlements once the event has passed. 
Perhaps the most famous rebuilding exercise in SPAs was associated with Cyclone Tracy. This cyclone hit Darwin (population of 40,000) in Australia's Northern Territory on Christmas Eve 1974, destroying over $90 \%$ of the housing and general building stock of the city. Over half of the city's residents were evacuated, with the population only returning in substantial numbers more than a year later once rebuilding had commenced. The population growth that was being experienced in Darwin before the cyclone quickly resumed by the late 1970s and even accelerated based on substantial in-migration associated with rebuilding and with the transition from dependent Territory to self-governing Territory status in 1978. However, it has been estimated that less than half of the population residing in the city in 1978 had also been at the time of the cyclone (Britton 1981). While the collective demographic characteristics (particularly age and sex distribution) looked quite similar, they were the characteristics of a new population, and the individual demographic impacts in terms of both out and in-migration were dramatic.

Cyclone Tracy may also have had different impacts on different population groups, with recent research (Haynes et al. 2011) suggesting much higher return migration rates of Indigenous people, and in-migration of Indigenous people from nearby communities which were also affected by the cyclone but which had less access to recovery and rebuilding resources. In a review of the literature on Indigenous migration responses to cyclones and other severe weather events, however, Carson et al. (2013) argued that the Cyclone Tracy experience may not be typical (nor may it be atypical) given that so many factors influence individual and collective behaviours. The review suggested that migration responses could differ depending on the extent to which: migration was forced [by evacuation policies, for example (Taylor and Freeman 2010)]; alternative residential locations were available nearby; resources were available to support both the out-migration and return migration; economic and cultural livelihoods were tightly linked to specific locations; and individual decisions were influenced by social and cultural group membership.

The literature on famines, cyclones and floods in SPAs suggests that demographic impacts are difficult to predict and dependent on a range of factors which need to be understood in their spatial, temporal and social contexts. Immediate impacts may be somewhat predictable based on exposure to risk (such as fatalities) and organisation of disaster response (such as forced evacuation), but longer-term impacts are subject to many intervening factors, including the difficulties associated with isolating the impacts of a single event from the ongoing dynamic and detailed nature of demographic change (see discussion on long-term population shifts in Chap. 2 as well). This argument can be further supported through the examination of the experiences of Gällivare and the Katherine-Daly area linked to the Great Deprivation and Cyclone Les respectively. While these cases are separated by 130 years, 14,000 km and a plethora of social, economic and political attributes, they demonstrate some of the ways in which demographic disruptions and diversions may emerge from natural disasters in SPAs. 


\subsection{Gällivare and the Great Deprivation}

While northern Sweden is often considered to have been slow to industrialise when compared with other parts of Europe (Engberg 2004), there is evidence that Gällivare was well advanced by the 1860s (Godet 2009). Industrialisation in Sweden tended to come first to rural primary sectors such as forestry and mining. This trend coincided with the dismantling of guilds and opportunities for private enterprise in manufacturing, thus, limiting urban industrialisation at least until after the liberal reforms of 1846 (Ryner 2003). During this time, Gällivare was in the Timber Frontier region, and the forestry sector experienced relatively rapid industrialisation after the introduction of the first steam-powered timber mills in the 1840s (Maas and van Leeuwen 2002). Gällivare was also at the forefront of mining development in northern Sweden, with commercial ore deposits near Malmberget (five kilometres north of Gällivare town itself) being extracted in the early nineteenth century. By the 1860s, British investors had secured funding to construct the first railway in Norbotten from Malmberget to the Lule River. Construction commenced in 1865, but was abandoned in 1867 due to financial strain (Godet 2009). There is no specific evidence that the Great Deprivation played a role in halting this initial construction, and, in fact, large projects such as railway construction would likely have been embraced by government as a means of providing employment for displaced rural workers during this time. The Swedish government did take over construction the railway, but poor planning and engineering meant that a working line did not eventuate in the region until 1888 . Nevertheless, mining developments were already occurring by the 1860 s, bringing with them new extraction and transportation technologies (Dewsnap 1981).

Likewise, while it was the impact of the railway on mining and forestry which led to the major economic and demographic development of Gällivare in the 1890s and early twentieth century, the signs of forestry industrialisation were already in place by the 1860 s. Northern Sweden as a whole was already exporting timber by 1860 , and the period of government regulation and management of forests as an export resource began in 1866 when England removed import barriers for Swedish timber (Axelsson 2014). During the second half of the nineteenth century, and particularly during the 1860s, there was a substantial consolidation of forestry ownership, with both government and private ownership focusing on larger landholdings. By 1872, new settlements were being actively discouraged in Sami pasture areas, which impacted the larger western parts of Gällivare, and led to a focus of development in the eastern quarter. Gällivare village itself had been settled in the early eighteenth century and became the centre of the Gällivare Parish formed in 1742. The Parish was dominated by small settlements up until the turn of the twentieth century, with just three villages having more than 100 population in 1860 (Gällivare, Ullatti and Nattavaara). Even by 1880, there were just six villages larger than 100 population (now including Hakkas, Leipojärvi and Nilivaara). Figure 5.2 shows the gross population development for Gällivare Parish between 1860 and 1880. The size of each dot represents the settled population of the village, with Gällivare Village in 1860 equating to 105 persons. 


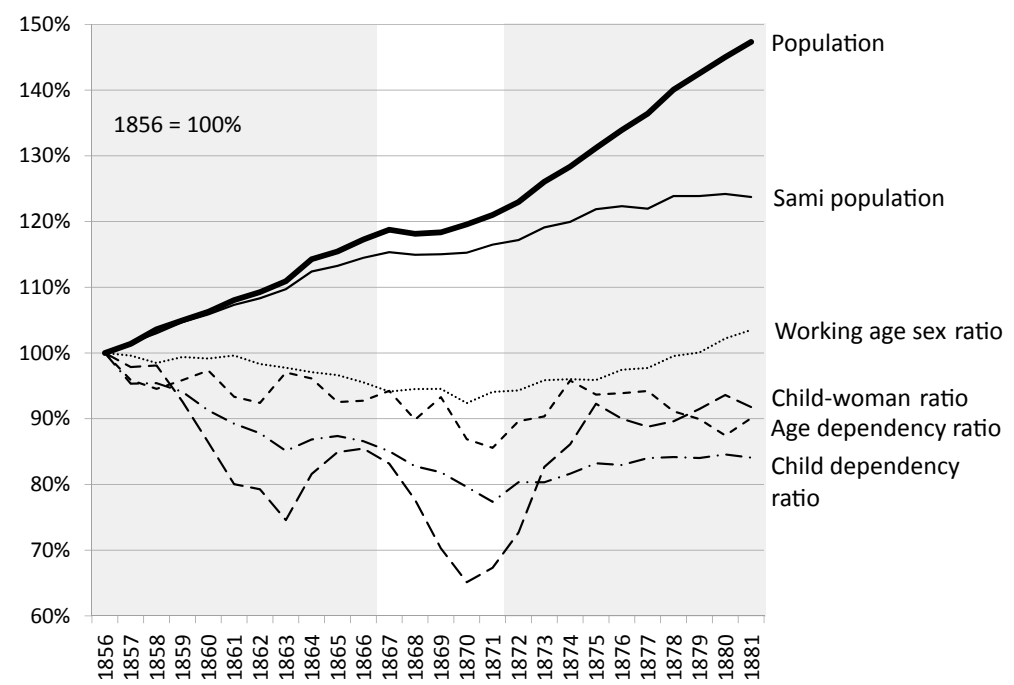

Fig. 5.3 Demographic Indicators for Gällivare, 1856-1881

Note that many Sami people (about 400 in both 1860 and 1880) were excluded from village population lists as they were still considered to be nomadic.

By 1865, Gällivare Parish had an estimated population of 2650 people, including nearly 1500 Sami people. There were 97 men for every 100 women, although this rate was much higher among non-Sami (104 men for every 100 women) population. Over one-third of the population (Sami and non-Sami) were aged under 15 years, and just five per cent (seven per cent of Sami) were aged 65 years and over. Annual in-migration rates for the past 10 years had averaged five per 1000 population, with out-migration averaging seven per 1000. Nearly two-thirds of the male population were employed in forestry or agriculture (and often in both) (Bäcklund 1988).

The short-term impacts of the Great Deprivation are apparent in a range of demographic indicators (see Fig. 5.3). These indicators are derived from data provided by the Demographic Data Base (DDB) at Umeå University. The DDB contains digitised parish records and links data on individuals identified in these records for most of the nineteenth century. Additional data were drawn from the 1890 and 1900 Swedish Census provided by the North Atlantic Population Project (NAPP). Figure 5.3 standardises indicators according to the 1856 value. The figure highlights the period 1867-1871, which has been considered the critical impact period (Isacson et al. 2013). Population growth stalled very early in this period but had resumed by the end. The Parish population was 2700 in 1866 and increased only to 2720 by 1869 , but then increased to 2782 by 1872 and continued to grow by between 1.5 and $2.0 \%$ per annum thereafter. The Sami population had been increasing rapidly up until the early 1860s but remained at 1500 people for the entire critical period. There was a brief period of growth again between 1871 and 1878 (to 1600 people), but the Sami population declined again to about 1500 people by 1900 (Karlsson 2013). 
The other indicators in Fig. 5.3 experienced decline throughout the entire critical period. The child-woman ratio (number of children aged 0-4 years for every woman aged 15-44 years) experienced the most dramatic decline, from about $85 \%$ of its 1856 value in 1866 , to just $65 \%$ of the 1856 value in 1870 . The ratio rose very quickly thereafter. The child dependency ratio (number of people aged 0-14 years for every person aged 15-64 years) also declined throughout the period. The age dependency ratio (number of people aged 65 years and over for every person aged 15-64 years) fluctuated throughout the period, but the general trend was a decline (indicating fewer older people). The small spike in this ratio in 1869 may be related to the 'dip' in working-age sex ratio (number of men per 100 women in the ages 15-64 years) in 1869-70. There is some evidence here of working-age males leaving Gällivare, probably via temporary migration to seek work in areas less affected by the famine (Dribe 2003). This also suggests only a small excess impact of the famine on mortality for older people (Edvinsson 2014). Interestingly, the period considered in Fig. 5.3 includes the 1857-58 famine, and there is some small evidence of decline in variables of similar type (but lower intensity) for those years.

The impact of the Great Deprivation on migration to and from Gällivare is difficult to ascertain. There was negative net migration (in the order of 10-15 persons per year) for four of the five years between 1867 and 1871, but negative net migration was not unusual and had occurred in 8 of the preceding 11 years and would occur in four of the following 10 years despite substantial population growth in that period. Population turnover was lower in the Great Deprivation critical period (10 per 1000 population) than the preceding (13 per 1000) or proceeding (12 per 1000) fiveyear periods. Of the 90 people who did leave Gällivare between 1867 and 1871, none were recorded as moving to North America, and just three moved to Norway. The remainder moved to other northern parishes within Sweden such as Råneå (20 migrants) and Överkalix (20 migrants). The destinations of migrants for 1867-1871 were similar to destinations in the preceding and proceeding five-year periods, with the exception that Norway was less popular in 1867-1871 (there were 14 migrants to Norway 1862-1866 and 13 in 1872-1876). There were 49 in-migrants to Gällivare between 1867 and 1871, with the majority again coming from other northern parishes where Överkalix and Jokkmokk accounting for more than half of all migrants. None were from Finland.

However, migration events may not have been well captured in the data, particularly short-term moves to find work or famine relief. The DDB does record 14 cases of people who moved out of Gällivare between 1867 and 1871 and moved back to Gällivare later. Only three of these were working-aged males (and one other male aged 14 years), while seven were working-aged females. Consequently, the migration events recorded during the period do not account for the relative decrease in the adult male population. Instead, there was an excess of adult male deaths (105 males died during the period compared to 92 females). In contrast, the period 1877-1881 saw 104 adult female deaths and 69 adult male deaths.

Mortality did not increase in Gällivare during the 1867-68 famine, crude mortality rates were 33 and 28 per 1000, but in perspective of the entire nineteenth century, these years mark a start of a high-mortality period that lasted until the end of the 
century (Sköld and Axelsson 2008). The dominant cause of death during the famine resulted from infectious diseases. Smallpox broke out in 1867 and measles followed in 1868. It is difficult to relate this to the starvation and suffering related to the famine, especially since these epidemics were nationwide. The Sami experienced a limited mortality increase around 1867-68 that was followed by similar peaks in the following decades. These changes were not dramatic when seen through a longterm perspective as they were not remarkable. Infant mortality actually decreased in Gällivare during the 1860s. The limited immediate impact on Sami populations may be explained in part by their capacity to use migration (a large proportion of Sami were at this time still nomadic) as a response to the famine threat (Sköld 1997).

After the Great Deprivation, the Gällivare population became more male (the total sex ratio rose steadily until the end of the nineteenth century, along with the working-age sex ratio), and less Sami. Gällivare also became more urbanised, with nearly three-quarters of the settled population living in villages with populations over 50 people in 1880, compared with just $47 \%$ in 1860 . Furthermore, the five largest villages contained less than $25 \%$ of the population in 1860 , which rose to approximately $30 \%$ in 1880 . However, this urbanisation was not apparent by 1870 with $47 \%$ of the population in larger villages and $23 \%$ in the five largest villages. So the Great Deprivation may likely have had a lesser impact than the processes of industrialisation in both the forestry and mining sectors, despite the more readily available famine relief in the larger towns (Engberg 2004).

\subsection{Katherine-Daly and Cyclone Les}

The Katherine-Daly river catchment area is home to about 21,000 people and consists largely of two broad demographic zones. The town of Katherine is a predominantly non-Indigenous $(70 \%)$ urban centre of 10,000 inhabitants whose location coincides with the main river crossing as well as the intersection of the only north-south and east-west sealed road transport routes in northern Australia. The surrounding region has over $85 \%$ of its population identifying as Indigenous, and features at least ten large (more than 200 people) 'Indigenous communities' - population centres located on Indigenous land and subject to specific legislation and regulations about who can live there.

Both Katherine town and the Katherine-Daly region have been well aware of the risk of flood events, with the site of the town shifted several times between initial European settlement in the late nineteenth century and the final siting that occurred once the railway bridge intended as part of the north-south railway line (not completed until 2004) had been constructed. The Indigenous inhabitants had long since adopted practices of temporary and longer-term migration to adapt to changing environmental conditions (Bird et al. 2013). While Katherine, like other large Northern Territory towns, was founded largely as a result of the Overland Telegraph line from Adelaide to Darwin, it quickly developed an entrepreneurial culture which distinguished it from the heavy government dependence typical of 
Northern Territory regional and local economies (Carson 2011). Katherine was one of the main service centres for the cattle industry in the north of Australia, was the site of experimental pastoral (cattle and sheep) and agricultural (peanuts and citrus) activities and had relatively large mining and manufacturing sectors in the 1980s and 1990s. The Katherine Research Station was opened in 1956 to inform agricultural and pastoral development.

The Katherine-Daly region was also at the forefront of tourism development in the north of Australia in the 1970s and 1980s. One of the first northern national parks was established at Katherine Gorge (Nitmiluk) in 1962. Tourism ventures originating in Katherine and focusing on Nitmiluk and Kakadu National Parks were very important contributors to the local and regional economy by the late 1980s when Nitmiluk National Park was handed back to its traditional Aboriginal owners (Berzins 2007). Faulkner and Vikulov (2001) report that Nitmiluk received nearly a quarter of a million visitors in 1997, and over 175,000 visitors stayed overnight in Katherine town, where the majority of accommodation infrastructure existed. While many visitors were self-drive, there were large organised tour markets, including 45,000 international visitors. Large tour companies such as Travel North were formed and based in Katherine, and large motels (many constructed in the late 1970s and early 1980s) dominated the accommodation market.

By the time of the January 1998 flood, however, there were signs that Katherine's development was slowing down. Attempts to sustain scheduled commercial air transport (subsidised heavily by the government) had largely failed. Travel North had been broken up into two companies, with some operations relocated to Darwin. Darwin had also supplanted Katherine as a major accommodation centre for people visiting Kakadu National Park, and even Nitmiluk National Park (Schmallegger and Carson 2010). Overall, visitor numbers to Outback Australia had begun a decline that continues to this day (Taylor et al. 2015). For the Katherine tourism region, visitor numbers have continued to decline since Faulkner and Vikulov's (2001) paper claimed that a 'bounce back' was likely. Visitor numbers did increase substantially in 2000 and 2001 (by approximately 15\% compared with 1999), but declined even more dramatically between 2002 and 2003 (by over 30\%) and continued to decline at least until 2013 (when visitor numbers were less than two-thirds of the 1999 benchmark).

While detailed data prior to 1996 are difficult to obtain, there is some anecdotal evidence at least, that other private sector activities such as mining and manufacturing in Katherine were also in decline before 1998 (Desert Knowledge Australia 2005). The Mount Todd mine, for example, was already in the process of winding down operations by 1997. Population growth had already plateaued by the 1996 Census at around 9500 people in the town, and 19,000 in the Katherine-Daly region as a whole. The balance between Indigenous and non-Indigenous residents of the town had also been shifting, with steady migration of Indigenous people from the surrounding region to the town observed at least since the early 1970s (Taylor 1989) and may have increased in the mid-1990s as a result of less support from government for Indigenous people living in very small communities in very remote areas (Altman 2006). The early impact of this migration had somewhat been hidden by the major 
expansion of the Tindal Airforce Base in the late 1980s, which brought nearly 2000 mostly non-Indigenous (and male) residents to the town.

The broad demographic experience of the town of Katherine in response to Cyclone Les and associated flooding in 1998 has studied by Harwood et al. (2011). Their work focused on the period from 1971 to 2006 reached some broad conclusions:

- The town experienced rapid population growth from the late 1970s (inspired by the establishment of a new military installation and the growth of the tourism industry) until the flooding, when population growth stagnated;

- There was a substantial change in economic geography, with the private sector and government administrative employment declining, and public services employment (education and health) increasing;

- There was a substantial change in the age distribution between 1996 and 2001, with an increase in the proportion of children aged under 15 years and people aged over 45 years at the expense of younger working-age adults;

- There was a substantial increase in the proportion of Indigenous people (from 18 to $25 \%$ of the population) and in the proportion of women in the population (from about $45 \%$ to nearly $50 \%$ ).

Harwood et al. (2011) focused on the town itself, although the floods affected the larger Katherine-Daly river catchment area. They did suggest that the increase in Indigenous population could be partially explained by the continuing migration of people from more remote parts of the area to the main town. While this migration may have increased after the flood (evidence is hard to find), the changing proportions of Indigenous and non-Indigenous people in town was likely more due to out-migration and a 'failure to return' (p. 317) by non-Indigenous people.

Harwood et al. assumed that the flood event was responsible for the immediate demographic change, and suggested, as did Faulkner and Vikulov (2001), that such impacts would likely be temporary. Katherine was expected to be well positioned to bounce back from this event. Partly, because the town's familiarity with flood events (big floods also occurred in 1957 and 1974, and since Cyclone Les there have been flood events in 2006 and 2014). Additionally, rapid recovery should arise because of Katherine's advantageous geographical position. Finally, because of the 'entrepreneurial spirit' which had underpinned rapid development during the 1980s and early 1990s, and the economic diversity and human capital which had accrued as a result. The expectation of rapid and full recovery (and even increased growth) existed despite $98 \%$ of businesses being affected by flood damage (James 2009).

Both Harwood et al. (2011) and Faulkner and Vikulov (2001) may have overestimated the capacity of the town in particular to recover economically and demographically as quickly as observed in Gällivare. Katherine town did not return to 1996 population levels until 2007, and its growth since has been predicated on the continued expansion of the public sector workforce, including substantial local government employment as local government offices for the surrounding region became located in Katherine town after local government reforms in 2007 (Michel 
and Taylor 2012). Public sector employment in health, welfare, education and protective services also increased dramatically as a result of the 2007 Northern Territory Emergency Response, an Australian Government programme designed to combat reported high levels of domestic violence and child abuse in Aboriginal communities (Taylor and Carson 2009).

In contrast to the town, population growth in the surrounding region averaged 2\% per annum from 1999 until 2013, with 1997-1998 gross population growth (72 persons) being low, but not unusually so. For the surrounding area, growth between 2003 and 2004 was estimated at 82 persons, between 2006 and 2007 (coinciding with another flood event) at 78 persons, and 2010 and 2011 at just 23 persons. In both Katherine and the region as a whole, Indigenous population growth outstripped nonIndigenous population growth, and the region became more female as well as more concentrated in the very young and the older age groups (Brokensha and Taylor 2014). No doubt the flood event was significant in the embedding of the new demographic trends reported by Harwood et al. (2011). However, there is some evidence that Katherine (particularly the town itself) was primed for such a demographic shift even before the 1998 flood event. The disaster may have served to exacerbate the new trends, rather than to create them.

\subsection{Explaining the Differences}

On the surface at least, Katherine appears to have experienced dramatic long-term consequences of Cyclone Les and the 1998 flood, while Gällivare suffered some substantial immediate impacts and relatively quickly returned to a pattern of demographic development which had been emerging by the mid-1860s. However, beyond the direct impact on individuals (which even so is difficult to assess), it is problematic to ascribe specific outcomes to the natural hazards. The dynamic nature of populations and economies in sparsely populated areas is well captured in these two case examples. For Gällivare, the impending mining and timber booms linked to northern settlement strategies, the introduction of industrial technologies, the opening up of global markets (particularly the UK) and the arrival of rail transport were the major drivers of demographic change in this period. There may be hints of correlations between Great Deprivation-induced activities such as the failed British attempt to construct a railway line or the increased Swedish government attention to forest regulation, but the literature has not teased these out to this point. For Katherine, the impending tourism 'bust' and the diversion of political attention and infrastructure investment to other locations in the north (principally Darwin) were likely very significant drivers of demographic change by the mid-1990s. It is likely that the processes of change would have occurred more slowly without the flood, but it is not by any means clear that the ultimate outcomes would have been much different.

The Gällivare story stands as an exception to some of the perceptions about the Great Deprivation-that it affected the north more than the south due to lack of 
industrialisation and that it resulted in substantial international emigration-but reinforces some others - that impacts were short lived, and that component effects (births, deaths, migration), while noticeable, were generally small. This reinforces the idea that spatial scale is important when examining the demographic impacts of natural disasters. Gällivare's experience must be somewhat unique given its economic, social and political resources, and, at least when it comes to economic circumstances, is likely to be importantly unique.

The spatial scale at which the 1998 flood disaster in the Northern Territory of Australia is examined has also proven important. A demographic diversion is clear when the town of Katherine alone is examined, but the broader region appears to have been less impacted. The town experience was more dramatic because of the starting economic and demographic conditions-not only that these were so different to the surrounding region, but because new trends which the flood would exacerbate in the short term had already been flagged. Consequently, those trends have persisted at least until the present day.

This research also includes an interesting comparison of affect-in Gällivare, the principal threat was to human life. Property was not much impacted by the bad seasons (although some land was not able to be used productively for a couple of years). In contrast, human life was not substantially threatened by the 1998 flood, but there was substantial property damage. This could explain the failure of Katherine to recover as expected, although property damage and the need to rebuild have elsewhere been considered drivers of Darwin's rapid recovery from Cyclone Tracy (Britton 1981). Loss of human life in a context of high mobility may actually be less important than the loss of physical infrastructure.

The research has highlighted the ways in which the dynamic processes of demographic change that typify sparsely populated areas make it difficult to identify the causes of specific changes, even where black swan events occur. Dynamic change makes it more possible for sparsely populated areas to absorb immediate demographic shocks within what are anyway often short-term demographic cycles. It also makes it easier to exaggerate trends which may have only been barely apparent prior to the event. 'Timing is everything', but interpreting the specific effects of the timing of a disaster presents challenges. In both cases, had the event been just a few years earlier, the impacts may have been vastly different. Resulting in perhaps more dramatic impacts for Gällivare than for Katherine. Timing influences the adaptations that are available for populations - are there economic alternatives? Are there migration opportunities? Are there systems in place to coordinate disaster response? The answers to these questions can change within even very short periods of time.

Similarly, the perception of impact of a disaster event can be altered by the temporal scale at which those impacts are viewed. It is only at a relatively fine scale (single years in this analysis) that the shock that Gällivare suffered can be seen in the surviving data. Perhaps examination at an even finer scale (seasons or months) could reveal even sharper impacts (Fellman and Eriksson 2001). In the case of Katherine et al. (2001) and Harwood et al. (2011) inability to stretch the timeframe of analysis sufficiently both prior to and after the event led to a misinterpretation of 
the economic and demographic context, and consequently a misunderstanding of at least the medium term economic and demographic potential.

The third attribute of a temporal scale is the relationship between the disaster event being examined and preceding and proceeding events of similar type. The annual modelling of demographic characteristics presented for Gällivare, for example, poses some interesting questions about the relationship between the 1857-58 famine and the Great Deprivation a decade later. While it is commonly assumed that people living in sparsely populated areas have heightened risk capacity as a result of frequent exposure (or expected exposure) to disaster events, the importance of the frequency of those events and the potentially different reactions of different social and economic groups are not well known. The slowdown in Indigenous population growth in the Katherine-Daly region around the time of the 2006 flood is also worthy of further investigation.

A lot more work additionally needs to be done on examining the social scale issues that have been flagged in this research. The experiences of women of the Great Deprivation in Gällivare may actually have been important in the long-term influencing both urbanisation (if even a few women moved to larger towns when their partners died) and masculinisation (if future generations of women were discouraged from in-migrating or encouraged to out-migrate) (see also Chap. 9). The evidence linking these processes and the event is currently unclear, and other methods (analysis of oral and written personal histories, for example) are likely to prove much more useful in creating such links than quantitative demographic analysis. The same can be said for understanding the role of the Great Deprivation and the Katherine floods in changing the behaviour of Indigenous people, an issue to which we have already been alerted in relation to Cyclone Tracy in Darwin in 1974 (Haynes et al. 2011).

In conclusion, the study of disaster events in sparsely populated areas is a task made particularly complex by the $D s$ of human geography in those areas. We can postulate that disaster events can lead to temporary disruptions in demographic development when existing trends are so dynamic and powerful as to readily absorb temporary shocks. We can also postulate that disaster events can lead to longer lasting demographic diversions when economic, political, social and demographic conditions are somewhat primed for change in any case (see also Chap. 6). We may not be able, however, to make any definitive statements of cause and effect except at the very fine spatial and social scale (essentially the attribution of individual behaviour). Rather, disaster events should be considered as one part of an ever present and dynamic set of influences on the human geography of sparsely populated areas.

\section{References}

Adamo, S. B. and A. de Sherbinin (2011). The impact of climate change on the spatial distribution of the population and on migration Population Distribution, Urbanisation, Internal Migration and Development: An International Perspective. P. D. United Nations Department of Economic and Social Affairs, United Nations: 161-195. 
Akenson, D. H. (2011). Ireland, Sweden and the great European migration, 1815-1914. Montreal, McGill-Queen's University Press.

Alestelao, M. and S. Kuhnle (1987). "The Scandinavian Route: Economic, Social, and Political Developments in Denmark, Finland, Norway, and Sweden." International Journal of Sociology 16(3/4): 3-38.

Altman, J. C. (2006). In search of an outstations policy for Indigenous Australians. Working Paper. Canberra, Centre for Aboriginal Economic Policy Research, Australian National University. 34.

Axelsson, E. (2014). The Forest as a Resource: conflicts in the northern Sweden wooded land in the 19th century. 54th European Regional Science Congress. St. Petersburg.

Bailey, A. J. (2011). "Population geographies and climate change." Progress in Human Geography 35(5): 686-695.

Bengtsson, T. and M. Dribe (2002). New evidence on the standard of living in Sweden during the 18th and 19th centuries. Lund Papers in Economic History. Lund, Sweden, Department of Economic History, Lund University. 82.

Berzins, B. (2007). Australia's northern secret: Tourism in the Northern Territory, 1920s to 1980s. Sydney, B. Berzins.

Bird, D., J. Govan, H. Murphy, S. Harwood, K. Haynes, D. Carson, S. Russell, D. King, E. Wensing, N. Tsakissiris and S. Larkin (2013). Future change in ancient worlds: Indigenous adaptation in northern Australia. Gold Coast, National Climate Change Adaptation Research Facility.

Britton, N. (1981). Darwin's Cyclone Max. An exploratory investigation of a natural hazard sequence on the development of a disaster subculture. Disaster Investigation Report. Townsville, James Cook University. 4.

Brokensha, H. and A. Taylor (2014). The demography of the Territory's 'Midtowns': Katherine. Darwin, Australia, Northern Institute, Charles Darwin University.

Bäcklund, D. (1988). I Industrisamhällets Utkant: småbrukets omvandling i Lappmarken 18701970. Umeå Studies in Economic History. Umeå, Sweden, Umeå University. 8.

Carson, D. (2011). "Political economy, demography and development in Australia's Northern Territory." Canadian Geographer 55(2): 226-242.

Carson, D., P. Ensign, R. Rasmussen and A. Taylor (2011). Perspectives on 'demography at the edge'. Demography at the Edge: Remote human populations in developed nations. D. Carson, R. Rasmussen, P. Ensign, L. Huskey and A. Taylor. Farnham, United Kingdom, Ashgate Publishing Ltd.: 3-20.

Carson, D. B., D. Bird, L. Bell and P. Yuhun (2013). "Migration as an Adaptation to Climate Change for Remote Indigenous Communities: What might we expect?" Inner Asia Studies in the Humanities 2: 92-111.

Carson, D. B. and D. A. Carson (2014). "Local Economies of Mobility in Sparsely Populated Areas: cases from Australia's Spine." Journal of Rural Studies 36: 340-349.

Desert Knowledge Australia (2005). Our Outback: Partnerships and Pathways to Success in Tourism. Alice Springs, Desert Knowledge Australia.

Dewsnap, R. (1981). "The history of the Lappland iron ore fields." Minerals and Energy - Raw Materials Report 1(1): 64-69.

Doblhammer, G., G. J. ven den Berg and L. H. Lumey (2013). "A re-analysis of the long-term effects on life expectancy of the Great Finnish Famine of 1866-68." Population Studies 67(3): 309-322.

Dribe, M. (2003). "Dealing with economic stress through migration: Lessons from nineteenth century rural Sweden.” European Review of Economic History 7: 271-299.

Edvinsson, R. (2014). Pre-industrial population and economic growth: was there a Malthusian mechanism in Sweden? Stockholm, Stockholm University.

Ellis, M. (2009). "Vital statistics." The Professional Geographer 61(3): 301-309.

Engberg, E. (2004). "Boarded out by auction: poor children and their families in nineteenth-century northern Sweden." Continuity and Change 19(3): 431-457.

Faulkner, B. and S. Vikulov (2001). "Katherine, washed out one day, back on track the next: A post-mortem of a tourism disaster Tourism Management." Tourism Management 22(4): 331-344. 
Fellman, J. D. and A. W. Eriksson (2001). "Regional, temporal and seasonal variations in births and deaths: the effects of famines." Social Biology 48(1-2): 86-104.

Ford, J. D., B. Smit and J. Wandel (2006). "Vulnerability to climate change in the Arctic: A case study from Arctic Bay, Canada." Global Environmental Change 16: 145-160.

Godet, L. (2009). Transforming Gällivare: the emancipation of destruction. Masters of Architecture, Ecol Polytechnique Federale de Lausanne.

Harwood, S., D. Carson, E. Marino and N. McTurk (2011). Weather hazards, place and resilience in the remote Norths. Demography at the Edge: Remote human populations in developed nations. D. Carson, R. Rasmussen, P. Ensign, L. Huskey and A. Taylor. Farnham, United Kingdom, Ashgate Publishing Ltd.: 307-320.

Haynes, K., D. K. Bird, D. Carson, S. Larkin and M. Mason (2011). Institutional response and Indigenous experiences of Cyclone Tracy. Gold Coast, Australia, Report for the National Climate Change Adaptation Research Facility.

Hayward, A. D., I. J. Rickard and V. Lummaa (2013). "Influence of early-life nutrition on mortality and reproductive success during a subsequent famine in a preindustrial population." Proceedings of the National Academy of Sciences 110(34): 13886-13891.

Hogan, A., D. Carson, J. Cleary, D. Donnelly, K. Houghton, R. Phillips and R. Tanton (2014). Community Adaptability Tool: Securing the wealth and wellbeing of rural communities. Canberra, Australia, Rural Industries Research and Development Corporation. 14/041.

Isacson, M., M. Morell, I. A. Flygare, T. Lennartsson, A. Dahlström and M. Eriksson (2013). Resilience of peasant households during harvest fluctuations and crop failures in Nineteenth century Sweden - a micro study based on peasant diaries. First EURHO Rural History Conference. Bern, Switzerland.

James, G. (2009). Katherine, Northern Territory. Risks from Climate Change to Indigenous Communities in the Tropical North of Australia. D. Green, S. Jackson and J. Morrison. Canberra, Department of Climate Change.

Jantunen, J. and K. Ruosteenoja (2000). "Weather Conditions in Northern Europe in the Exceptionally Cold Spring Season of the Famine Year 1867." Geophysica 36(1-2): 69-84.

Karlsson, L. (2013). "Indigenous life expectancy in Sweden 1850-1899: Towards a long and healthy life?" Demographic Research 28(16): 433-456.

Koch, A. and D. B. Carson (2012). Spatial, Temporal and Social Scaling in Sparsely Populated Areas_-geospatial mapping and simulation techniques to investigate social diversity. GI_Forum 2012. Salzburg, Austria.

Maas, I. and M. H. D. van Leeuwen (2002). Occupational careers of the total male labor force during industrialization: the example of nineteenth-century Sweden. Origins of the Modern Career. D. Mitch, J. Brown and M. H. D. van Leeuwen. Aldershot, Ashgate: 258-277.

Martel, C., D. Carson, E. Lundholm and D. Muller (2011). Bubbles and Craters: Analysing Ageing Patterns of Remote Area Populations. Demography at the Edge: Remote human populations in developed nations. D. Carson, R. Rasmussen, P. Ensign, L. Huskey and A. Taylor. Farnham, United Kingdom, Ashgate Publishing Ltd.: 107-124.

Martel, C., D. Carson and A. Taylor (2013). "Changing patterns of migration to Australia's Northern Territory: Evidence of new forms of escalator migration to frontier regions?" Migration Letters 10(1): 101-113.

McLeman, R. (2010). "Impacts of population change on vulnerability and the capacity to adapt to climate change and variability: a typology based on lessons from "a hard country"." Population and Environment 31: 286-316.

McLeman, R. and B. Smit (2006). "Migration as an adaptation to climate change." Climate Change 76: $31-53$.

Michel, T. and A. Taylor (2012). "Death by a thousand grants? The challenge of grant funding reliance for local government councils in the Northern Territory of Australia." Local Government Studies iFirst: $1-16$.

Nelson, M. C. (1988). Bitter Bread: the famine in Norrbotten 1867-1868. Uppsala, Uppsala University. 
Newby, A. G. (2014). "“Neither do these tenants or their children emigrate": famine and transatlantic emigration from Finland in the nineteenth century." Atlantic Studies: global currents 11(3): 383-402.

Nordin, G. (2009). Äktenskap i Sapmi: giftermålsmönster och etnisk komplexitet i kolonisationens tidevarv, 1722-1895. PhD, Umeå Universitet.

Nordin, G. and P. Sköld (2012). "True or false? Nineteenth-century Sápmi fertility in qualitative vs. demographic sources." The History of the Family 17(2): 157-177.

O Grada, C. (2007). "Making famine history.” Journal of economic Literature 45(1): 5-38.

Ryner, J. M. (2003). Capitalist restructuring, globalism and the third way: lessons from the Swedish model. London, Routledge.

Saxton, K., A. Falconi, S. Goldman-Mellor and R. Catalano (2013). "No evidence of programmed late-life mortality in the Finnish famine cohort." Journal of Developmental Origins of Health and Disease 4(1): 30-34.

Schmallegger, D. and D. Carson (2010). "Whose tourism city is it? The role of government in tourism in Darwin, Northern Territory." Tourism and Hospitality: Planning and Development 7(2): 111-129.

Sköld, P. (1997). "Escape from catastrophe: The Saami's experience with smallpox in eighteenth-and early-nineteenth-century Sweden." Social Science History: 1-25.

Sköld, P. and P. Axelsson (2008). "The Northern Population Development. Colonization, and mortality in Swedish Sápmi 1786-1895.” International Journal of Circumpolar Health 67(1): $29-44$.

Taylor, A. (2011). The forecasting of remote area populations: numbers aren't everything. Demography at the Edge: Remote human populations in developed nations. D. Carson, R. Rasmussen, P. Ensign, L. Huskey and A. Taylor. Farnham, United Kingdom, Ashgate Publishing Ltd.: $39-52$.

Taylor, A. (2014). "Population projections for sparsely populated areas: reconciling 'error' and context." International Journal of Population Research early view.

Taylor, A. and D. Carson (2009). "Indigenous mobility and the Northern Territory Emergency Response.” People and Place 17(1): 29-38.

Taylor, A., D. B. Carson, D. A. Carson and H. Brokensha (2015). “'Walkabout' tourism: The Indigenous tourism market for Outback Australia." Journal of Hospitality and Tourism Management 24: $9-17$.

Taylor, J. (1989). "Public policy and aboriginal population mobility: insights from the Katherine region, Northern Territory." Australian Geographer 20(1): 47-53.

Taylor, M. A. P. and S. K. Freeman (2010). "A review of planning and operational models used for emergency evacuation situations in Australia." Procedia Engineering 3: 3-14.

Open Access This chapter is licensed under the terms of the Creative Commons Attribution 4.0 International License (http://creativecommons.org/licenses/by/4.0/), which permits use, sharing, adaptation, distribution and reproduction in any medium or format, as long as you give appropriate credit to the original author(s) and the source, provide a link to the Creative Commons license and indicate if changes were made.

The images or other third party material in this chapter are included in the chapter's Creative Commons license, unless indicated otherwise in a credit line to the material. If material is not included in the chapter's Creative Commons license and your intended use is not permitted by statutory regulation or exceeds the permitted use, you will need to obtain permission directly from the copyright holder.

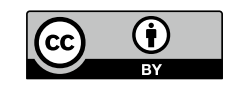

